\title{
Economic Impacts of Forest Policy Changes: A Perspective from Nepal
}

- Keshav Raj Kanel, Ph.D*

\section{Introduction}

Forest is one of the leading renewable resource providing safety nets for the poor and vulnerable, products for markets and for value addition and sustaining the biodiversity and environmental health in the context of Nepal and beyond. Forested area covers about 39.6 percent of Nepal and is also the major tourist destination. Forests also provide forward and backward linkages to other sectors. Forest, farming and animal husbandry are intimately related as about 40 percent of the livestock feed is derived from forests and trees grown on farm. Organic manure mixed with leaf litter is the major source of fertilizer to replenish the productivity of the agricultural area. Similarly, major share of energy is derived from fuelwood. Moreover, Non timber Forest products (NTFPs) including Medicinal and Aromatic Plants (MAPs) provide both household and market products. Public and external benefits derived from these forested areas are soil and water conservation (upstream and downstream benefits), carbon sequestration, and biological diversity. These multiple benefits have not been adequately considered in the national accounting although the forests are of vital importance for national economy. How to supply these multiple benefits in a sustainable way so that they are mainly captured by Nepali citizens for both broad based economic development and livelihood promotion is the agenda for policy debate in the forestry sector development.

The objective of this paper is to analyze the consequences of different policy regimes, the internalizations of lessons learned from our experiences, and to present some of the policy gaps for further research so that forest resources could be optimally managed. After this introductory section, the other two sections of the paper present the key characteristics of forest management, which need to be and are considered in crafting forest policy in Nepal. The fourth section analyses the forestry policy in action over time in Nepal. The impact of policy reforms in community forestry, which can be considered as a case study, is presented in the fifth section. The final section presents concluding remarks and some of the topics for policy research in the context of Nepal.

\section{Policy at a Glance}

Why should we talk or discuss about policy in forest management? We discuss and analyze it because policy is an important ingredient in making decisions. It provides signals for decision makers or actors. Decision makers at various levels consider it as an input in making their decisions. It may allow, permit or hider actions relevant to actors. If a policy has to be effective, it has to be binding. Other wise, it merely forms a statement of good intention: intention may be sublime but the result may be otherwise. To make the policy binding or that the actors follow it through, the implementation capacity of the policy enforcing organizations should also be strengthened. Therefore, policy is important in reducing uncertainty associated with planning programs and their implementation.

A policy can be defined and assessed from different dimensions. Here, we assess it as an enabling mechanism and its consequences. It recognizes the interdependency between natural and human systems. The interactions between these systems provide the foundation for the formulation of forest policy. The stated vision for forest policy is to enhance and expand its contribution to poverty reduction, environmental security, good governance, social justice and intergenerational equity through sustainable, equitable and effective management and responsible use of the nationwide forest resources. This vision for policy is also mentioned in the interims planning document (2008 - 2010), and the Master Plan for Forestry Sector (MPFS) development.

* Director General, Department of Forests, Nepal 
Policies can be decomposed into two types: regulatory and fiscal. Regulatory policy is related to control and command. The fiscal policies are related to taxes or subsidies which affect forest management. These policies are not only relevant to the decentralized units but also to the centralized entities. Decentralization of regulatory policy appears to be easier than the fiscal mode of decentralization. In the context of Nepal, communities have the authority of access, withdrawal, management and exclusion but not the alienation (Schlanger et al., 1992) in the management of their forests. Fiscal decentralization has occurred with respect to community and leasehold forests. But there is a contentious issue related to the way revenues from the sale of forest products is shared among the central and local government, and the community forest user groups.

Policies that originate from non-forestry sector also affect the way forests are managed at a local level. Oil boom may lead to expansion of economic activities that may lead to conservation of forests due to the reduction of dependency on forest resources (popularly known as Dutch Disease). Road construction through forest increases the alternate value of the forestland and thus, exerts pressure for forestland use conversion such as the accelerated deforestation in the Terai. Similarly, macro-level monetary, and fiscal policies also affect allocation of forest land and the intensity of forest management. Increased poverty at the macro level has induced hill people to migrate to the Terai and encroach the forests while looking for alternative employment opportunities.

Many policies including forestry have been designed to sustainably manage the forests for environmental conservation and economic development. However, the monitoring and enforcement capacity of the administrative arm of the government remains weak. Therefore, there needs to be congruence between policy formulation and enhancement of implementation capacity. The Master Plan for the Forestry Sector has stressed the importance of reorientation of forestry staff and their capacity growth, so that they could play more of a facilitative role in the management of forests

\section{Characteristics of Forest Management}

Forests provide goods and services, which are valued by society for various purposes. The process of producing and using these benefits has some unique characteristics as listed below:

Forests generate multiple products and services, which are competitively marketed or undervalued or provided through missing markets. Some products act as safety nets for the most vulnerable groups such as the collection and sale of MAPs mainly from the hills and mountains.

Goods and services such as timber and fuelwood, or the production of leaf, wood, MAPs and other ecological services are jointly and simultaneously produced from the same area. How to allocate separate cost among these jointly and simultaneously produced products and services is a challenging task.

Many people depend on forests for different uses. So, exclusion is difficult. Similarly, the stock of forest yields products (private goods), which are substractible (meaning if it is used by some one, the same is not available for others to use).

Forests cover extensively in area and low in terms of labor use, and rotation period is long (opportunity cost of land and capital locked in trees is high, but flexibility in harvesting is longer than say in agriculture).

Forests also generate joint production of private and public goods, which are related to the issue of investment and externality. These pose the question-who pays and who gains?

Externalities from forests are Watershed management, Biodiversity conservation, and Carbon sequestration. Who captures the values? How the distance users pay for the services of these public good or externalities? How to value the goods and services? How to include them in decision-making? Forests of Nepal are now mostly residual land use. This leads to the question of property rights and enforcement. If the cost of ownership/management rights exceeds benefits, forests get converted to open access resource. As the value of benefits from forests and the alternative uses of the forestland increases, the institutional regime 
to manage them has to be changed. Consequently, types of property rights and their enforcement are very important in the sustainable management of forests. Production and use of public and private goods and services from the same unit area and management entity leads to government (policy) and market failure. This has led to the policy prescription of centralization and or privatization in the management of forests.

\section{Forest Policy in Action}

Nationalization of the forests in 1957 transferred the ownership of forestland to the state. One of the reasons of nationalization was that these forests were of strategic importance for the national economy, besides producing not only the private goods but also the public goods and services (such as watershed value and environmental functions). However, since the state could not enforce its own rules in the management of these forests, forest depletion and deforestation accelerated. This is also a classic example of government policy failure because state as a landlord (absentee landlord) creates its own problem - principle and agent problem, and moral hazard.

Several factors already enumerated in section two also highlight the fact that market does not effectively operate in the conservation and management of forests. In addition to the above factors, the locals have time and space knowledge of the condition and use of forests. Moreover, monitoring and enforcement costs are non trivial in forest management. Similarly, goods and services jointly produced and used by distance users also create problems of market failure.

Forest policy reforms were initiated in 1978 (revision of forest act), 1989 (approval of MPFS), 1993/95 (new forest act and regulations), 2000 (new forest policy - collaborative forest management and protected forest management; revenue sharing among CFUG and central government, and the Poverty Reduction Strategy Program (Tenth Five Year Plan). Some of the salient features of these policy measures are enumerated below:

Polycentricity-National and Private forest ownership, Involvement of other overlapping organizations (CFUGs, Leasehold forest groups, District and Village Development Committees, and other coordinating institutions such as District Forest and Village Development Coordination Committees). Non-Government Service Providers are also increasingly involved in providing services to forest users, and the government.. Decentralization - De-concentration of power to the District Forest Offices (DFOs), and devolution of forest management power to CFUGs, leasehold forest groups, and revenue sharing mechanism between government and District Development Committees (DDCs)

Participatory decision-making - Rights, responsibilities, risk and rewards differentiated among CFUGs, DFO, DDCs/VDCs (in Community and Collaborative forest management).

Decentralized and robust organizations are important in sustainable management of the forests. Similarly, forest management activities are now linked with livelihood promotion in the rural areas.

Annual budget of the forestry sector (Nrs 2.3 billion or 1.37 percent of total budget), with an allocation of about 35 percent of total development budget in CF. There is very little international loan in the forestry sector. However, other sectors relying on loan are considered as the priority sector, but not the forestry sector. This is a dilemma in prioritizing the sector development in Nepal.

\section{Experiences from Community Forests}

The experiences of community forestry gained over the last 25 years show some positive impacts in terms of enrichment of greenery and growing stock. On the other hand, forests under government management systems are not only depleting but also degrading. Some basic facts on community forests indicate that Community Forest User Groups are also generating financial resources, which are used mainly in better forest management and community development activities. 
Forested area (forests and shrubs) cover about 39.6 percent of land area or 5.8 million hectares. Out of this total forested area about 18 percent is under community forests. Since about ten percent of forested area is estimated to be under protected areas, it can be estimated that $25 \%$ of National Forests (forested areas outside protected areas) are under community forests. More than 14,000 CFUGs or $35 \%$ of total population manages these forests officially. The CFUGs charge nominal price to the forest products used by the users themselves. Only the surplus products are sold at a competitive price.

The Community Forest Division undertook a rapid appraisal of 1,788 CFUGs during 2004. We extrapolated the income and expenditure pattern from these sampled CFUGs to the total CFUGs of Nepal. The result shows that annual income from the community forests to the CFUGs is about Nepali Rupees (NRs) 747 million, but if we add up other income (fines, fee and grants etc), the total income accruing to CFUGs amounts to about NRs 913 million. By comparison, the total revenue of the Department of Forests for the last fiscal year was only NRs 450 million. Some of the highlights of this financial appraisal is presented in the box 1 .

Analysis of the expenditure pattern shows that users groups spend about 50 percent of their income, and retain the other half in their accounts. The data shows that the CFUGs spend about 28 percent on forest protection and management. Another 36 percent is spent on community development activities. Moreover, they also spent about 17 percent on miscellaneous items, which is difficult to define. Only about three percent of the total income is spent on operational cost.

The groups are also creating and using other capital assets such as physical, human and social including the natural and physical ones just described. The creation of physical assets come under the rubric of community development activities such as drinking water, school, school construction at the local level. Imparting of training (skill and knowledge, informal education) has helped to strengthen the human capital of the users. Legitimization of the CFUG as an incorporated body and the process of democratization at the CFUG have strengthened the social capital of the users. In addition, saving and micro-credit arrangement initiated at the CFUG level has reduced the vulnerability of the poor, although at a small scale. The initiatives and innovation in community forests have been extended

\section{Box 1: Highlights of financial Appraisal of Community Forest}

Terai (plain region lying south and adjacent to India) has less than 10 percent of community forests, but generates more than 26 percent of this income. Household income from this community forest is NRs 1,173 in the Terai but only NRs 512 in the hills/mountains.

The main source $(82 \%)$ of income is from the sale of forest products. The share is $90 \%$ for the hills/mountains but is only $59 \%$ for the Terai. If we value the forest products harvested from the community forest at a market price, it worth about NRs two billion.

in the management of micro-watersheds. Now, Community Development Groups (CDGs) initiate watershed management activities in the field and the government officials facilitate the social mobilization process. Similar is the case in the management of Buffer Zones around the National Parks and Reserves.

Although community forestry is successful in decentralizing forest management activities, and creating greenery and financial capital through CFUGs, time has come to tackle second-generation issues in community forestry. Related to these issues is also the question of recognizing the role of forests in broad-based development and linking it to poverty reduction in the rural areas of Nepal.

The following are some of the important issues that need to be resolved as community forestry moves ahead in the $21^{5 t}$ century. They are identified below:

The second-generation issues focus on livelihood/equity, good governance, enterprise development and marketing of forest products, and sustainable forest management. The elected committee members, and rural elites capture most of the benefits from 
the forests and their funds. How to design inclusive process of decision-making and benefit sharing so that poor, women and Disadvantaged Group (DAG) members get benefits from the forests and the funds of the CFUGs is a challenge in livelihood/equity? Income generation through MAP intercropping, establishment of enterprises and the marketing of the forest products are also very important in livelihood promotion. The second issue is related to good governance in the operation of CFUGs and the relationship with the DFO. The transaction cost of CFUG formation and their operation is substantial and how to reduce this cost is also a challenge? The components in good governance are rule of law (the same rule applies to the ruler and the ruled), transparency in decision-making, accountability and responsiveness. The third is the sustainable forest management. Since many of these forests are still protection oriented, the task is to enhance productivity of the forests and at the same time retain the biodiversity conservation.

How to involve the genuine users in the management of Terai forests when the genuine users are marginalized by the forest encroachers or legally settled migrants? The forests of the Terai are commercially valuable and also a major source of government revenue. If these forests are handed over to the CFUGs, what should be the revenue sharing process and mechanism between the government and the CFUGs? Presently, the government collects 15 percent of the revenue from the sale of surplus Sal and Khair timber obtained from the community forests. Should it be collected by the local political bodies?

The mountain region has low density of population, and extensive area of forests and rangeland. The community forestry model developed and practiced in the hills with high density and scarce land is not very suitable for the management of mountain forests and rangeland. How to design institutional arrangement so that the resources are sustainably managed and products equitably used is a major problem. Commercial harvest and transit permits for the forest products are issued by the forest officials. The transaction cost of the permit regime is substantial. How to reduce this cost?

Technology of production and processing of Non Timber Forest Products (NTFP) and MAPs is not easily available or has not been innovated and non-tariff barriers to market access to the raw or the processed products are getting tougher. Global warming is an international challenge. Forests conserve carbon, and hence help in reducing global warming. How to link the relationship between Clean Development Mechanism (CDM) and forest management should be one of the important development dialogues in Nepal.

There are differential perspectives on how the forests should be managed and who should get the benefits at what cost. For example, CFUGs consider that they should capture the product benefits or the total revenue; Local level political bodies consider that they should own the forest, and thus share some of the financial revenue. Politicians at the center and the forest officials working with the government think that the government should allocate some part of forests to the communities and the government should also get some revenue from these forests as well. Conservationists consider that larger area should be locked up as national parks or reserves. Donors and the Finance Ministry consider that the sectors getting loan should be the priority areas for development. How to reconcile these differential perspectives by the Ministry of Forests and Soil Conservation? Theoretically, it should be carried out through political process. But if the process is so muddy, how to execute the programs by the government officials?

\section{Conclusions and Topics for Further Research}

Property rights over forests are very important in the management of forests. As the resources become scarce, property rights have to evolve. This induced innovation has to be facilitated by the government policy. In other words, enabling policy regimes have to be designed so that the objectives set in the policy are achieved through the actions of relevant stakeholders. Policies and institutions create incentives so that the behavior of decision makers is streamlined to attain the objectives of the policy. The role of government is as important as that of people's organization in forest management. Case studies from China suggest that regulatory reform provides substantial incentives for better management. If it 
could be matched with fiscal measures, forest could be further promoted in the landscape.

Forests create externalities and environmental services to distance users. Devising a mechanism of capturing the external benefits to the producers of these beneficial externalities and public services would further enhance forest management. Development of simple and useful valuation techniques to measure these services is a must before asking for the payment of these services.

Forests provide opportunities for conservation, and broad-based economic growth compatible with livelihood promotion. If the higher-level decision makers recognize this relationship, forests and forestry should get priority in national development. An example of community forestry program from Nepal indicates that community mobilization is essential for forest management and sustainable utilization, and for community development. How to link this development to livelihood promotion of the poor households is the challenge in community forestry. How to ensure that substantial fund generated from the community forests could be canalized towards pro-poor programs? What about the role of enterprise development and marketing of the products so that poor can be the proprietor and managers of these commercial yet viable enterprises?

Forest policies have been stated in many documents. It is observed that forest polices and other policies coming from other sectors have influences in the way forests are managed at the local level. How to harmonize these multiple policies and to increase the capacity of these polycentric organizations is also the challenge in policy design. Mere inflation of policies does not necessarily lead to good implementation and result. Therefore, more focus should be given to the enhancement of implementation capacity of decision makers.

\section{REFERENCES}

Adhikari, Bhim. 2003. Property rights and Natural Resources: Socio-Economic Heterogeneity and Distributional Implications of Common Property Resource Management. Working Paper No 1.03. South Asian Network for Development and Environmental Economics (SANDEE), Kathmandu, Nepal.

Hyde, W.F., and G. S. Amacher, and Colleagues (eds). 2000. Economics of forestry and rural development. An empirical introduction from Asia. The University of Michigan Press.USA.

Hyde, W.F., B. Belcher, and J.Xu. (eds.) 2003. China's forests global lessons from market reforms. USA, Washington: RFF Press.

James Mayers and S. Bass. 1999. Policy that works for forests and people. Policy that works for forests and people series no: 7. International Institute for Environment and Development. London.

Kanel, K., M. B. Karmacharya and B. K. Karna. 2003. Who benefits from institutional reforms: case studies from four community forests. In Kanel et al. (eds.) Human-Institutional Natural Resources Interactions: Understanding the interface between social and natural resources systems. Proceedings of a seminar. Rising Son Printers, Kathmandu, Nepal.

Kanel, K.R. 2001. Forests, Collective Action, and Policy Instruments in Nepal: Aligning Decentralization with Fiscal Responsibility. In Enabling policy framework for successful community-based resource management. Proceedings from the Ninth Workshop on community-based management of forestlands. Edited by Suryanata, S., G.Dolcemascolo, R.Fisher and J.Fox. East-West Center and Regional Community Forestry Training Center.

Michael R., J.Davies and G.Yaron. 2003. Stakeholder incentives in participatory forest management A manual for economic analysis. ITDG Press. London.

Ostrom, E. 1990. Governing the commons The evolution of institutions for collective action. Cambridge University press.

Scheer, S. J.; A.White, and D.Kaimomitz. 2004. A new agenda for forest conservation and poverty reduction Making markets work for low-income producers. Forest-Trends. Washington D.C., USA. 
Schlager, E, and E.Ostrom. 1992. Property-rights regimes and natural resources: a conceptual analysis. Land Economics 68: 249-262.

Wunder, S. 2003. Oil wealth and the fate of forest a comparative study of eight tropical countries. Routledge.

Note: This paper does not necessarily represent the views of the organization with which the author is presently associated. The author can be reached at keshavkanel@yahoo.com

$$
\because 8
$$
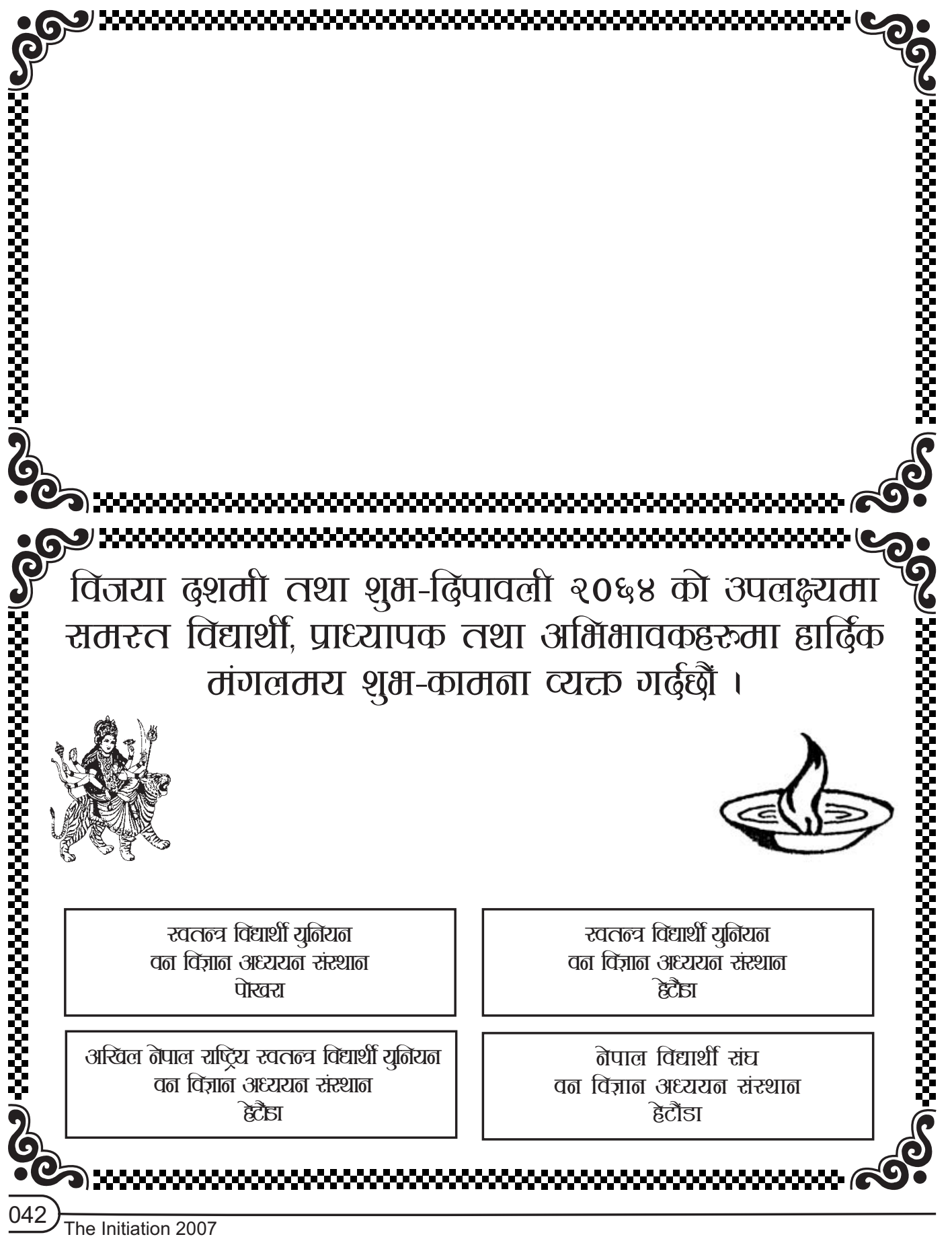